\title{
CARTELS AS BARRIERS TO INTERNATIONAL TRADE
}

\author{
WENDELI Berge*
}

In the pilgrimage of mankind toward the achievement of a peaceful and prosperous international society, the most difficult and persistent of all phases of world affairs are not solely political or military. The political and military relationships interact continuously with the economic developments which affect the production and distribution of the world's goods.

In a period of world upheaval it becomes necessary to re-examine the economic basis of international affairs. An analogy may serve to underscore the need. It has been publicly announced that at a selected date an atomic bomb will be released at a chosen site in the Pacific Ocean. There, by what is known as a chain reaction requiring only a fraction of a second, the colossal power of modern science will demonstrate once more its mastery over matter. This test has been designated as "Operation Crossroads," a dramatic description of its significance. In a sense the problem involved in this undertaking is clear-cut; its terms are explicit. But the reconstruction of world trade is also an "Operation Crossroads" which must be undertaken because there is no choice. In many respects also, the questions posed by the future of international trade require as intricate analysis, have as many complex ramifications and are as delicate in their adjustment as any of the questions of atomic science.

What is done in the sphere of world trade within the next few years will also cause a chain reaction for good or ill throughout the world economy. To a particular country, to many industrial enterprises and to many individuals, international trade may seem to be of small direct concern. But trade whether small or large in volume is not only the point of most direct contact among the nations of the earth; it is also the area of decision in which the expressed hopes and desires of nations to create a peaceful and prosperous world society will be most shortly visible. All the pressures, all the tensions and all of the conflicts and policies accumulated on other levels of international life are ultimately reflected at the point of trade policy. Conversely, small frictions and disturbances which have their origin in specific trade situations may radiate outward and charge the atmosphere of inter-

* A.B., University of Nebraska, I925; LL.B., I927, S.J.D., 1930, University of Michigan. In practice, New York City, 1928-1930. With Antitrust Division of the Department of Justice since 1930. Since 1943, Assistant Attorney General of the United States and head of the Antitrust Division. Member of District of Columbia Bar, Federal Bar Association, American Bar Association, American Judicature Society. Author: Cartels: Challenge to a Free World (1944); Economic Freedom for the West (1946). Contributor to legal periodicals. 
national life with corrosive influences. Trade is, therefore, a principal focus of all those forces which tend to disrupt or adjust the world economy. To resolve the problems of world trade is to go far toward the solution of the entire question of world relations.

There are alternatives. Nations may engage in patient efforts to understand, to cooperate and to exchange products with one another. Nations may refuse to pursue this way-admittedly the more difficult-by shortsightedly following the lines of least resistance. If this happens, trade will then proceed, if at all, along primitive paths in the jungle of economic warfare, dimly illumined in an international twilight of suspicion and fear, closed markets, retaliatory tactics and the ever-present shadow of war.

It is particularly necessary at this juncture in world affairs to remind ourselves that the progress of civilization has in large part been measured by the growth of world trade. In one respect what we call international trade is the oldest form of commerce. At its inception, all trade beyond the bounds of a village was considered foreign. Over the course of the centuries as larger areas came under single sovereignty, "foreign" trade took on new meaning as intercourse among states, nations and empires. Today we speak of international trade, of interregional trade, of intercontinental trade, of trade between hemispheres, of world markets and of a world economy. To the extent that these have meaning, policies and circumstances which affect trade must necessarily have repercussions throughout the entire realm of world relations. Tacitly, of course, the degree of interdependence is almost an axiom of our thinking. We know that discriminations which begin in trade have a tendency to become generalized and affect political dealings. We know that trade is a barometer of politics anticipating the political climate which the morrow will bring. We know that a rise or decline in trade is almost automatically translated into prosperity or depression in many national economies.

It is a simple matter to say that the crux of the whole issue of trade as it presents itself today is whether the United States and the other United Nations will work consciously toward greater freedom of trade or whether they will permit the restrictions and barriers which are inherited from the past to circumscribe their attitudes and their policies. To state this, however, does not help us very much in deciding what should be done, nor does it tell us why barriers to trade have come to be what they are, or how to alleviate them.

To come to realistic terms, it must be recognized that the world economy is in a plight which has no parallel in the past. Within the last half century, both war and peace have resulted in the infliction of extreme injuries to the conditions of world trade. During the late nineteenth century and, indeed, until August, rgI4, there seemed to be ground for belief that increased freedom of trade was the natural course of evolution. In economic affairs, the elimination of the vestiges of feudal thought and mercantilistic practices had been the great crusade of the nineteenth century. Apparently the ease with which goods moved in the first decade of the 
twentieth century represented a triumph of international intelligence, the successful culmination of that philosophy of production and distribution which had been born in the age of Manchester liberalism.

The late John Maynard Keynes has given us a graphic description of the trade environment which prevailed at that time. In his "Economic Consequences of the Peace," he stated:

"What an extraordinary episode in the economic progress of man that age was which came to an end in August, rgr 4 ! . . The inhabitant of London could order by telephone, sipping his morning tea in bed, the various products of the whole earth, in such quantity as he might see fit, and reasonably expect their early delivery upon his doorstep; he could at the same moment and by the same means adventure his wealth in the natural resources and new enterprises of any quarter of the world, and share, without exertion, or even trouble, in their prospective fruits and advantages; or he could decide to couple the security of his fortunes with the good faith of the townspeople of any substantial municipality in any continent that fancy or information might recommend. He could secure forthwith, if he wished it, cheap and comfortable means of transit to any. country or climate without passport or other formality, could despatch his servant to the neighboring office of a bank for such supply of the precious metals as might seem convenient, and could then proceed abroad to foreign quarters, without knowledge of their religion, language, or customs, bearing coined wealth upon his person, and would consider himself greatly aggrieved and much surprised at the least interference. . . . The projects and politics of militarism and imperialism, of racial and cultural rivalries, of monopolies, restrictions, and exclusion, which were to play the serpent to this paradise, were little more than the amusements of his daily newspaper, and appeared to exercise almost no influence at all on the ordinary course of social and economic life, the internationalization of which was nearly complete in practice."

The first World War shattered whatever reality there was in this conception. - Moreover, the consequences of the war led many students of economic affairs to believe that freedom of trade, even at its best, had been a fleeting illusion, the day dream of a comfortable Victorian world. There was, of course, a tremendous surge of trade in the period after I9I9, but it was no longer conducted along the old lines. Rather it was trade hedged about by every conceivable form of restriction, through which governments and traders alike indulged in practices reminiscent of mercantilism. Actually, of course, the resemblance was superficial, for mercantilism at its worst did not entail the serious results of the policies which prevailed from rgrg until r939.

The world of rgr3 cannot be restored, and no one would want to do so. But the world of 1919 , or of 1929 , or even of 1939 , must not be used as a yardstick, lest we risk the same cycle of economic and political tragedy. If we examine the factors which have been primarily responsible for the economic warfare of the past quarter of a century and the factors which represent the greatest threats to the achievement of freer world trade, it is clear that all of them have their roots in a philosophy of restriction. This philosophy is not reflected simply in the system of prohibitive tariffs and foreign exchange control which constituted so great a burden upon world 
trade during the 1920 's and $1930^{\prime}$ 's. This same philosophy, in a form more widespread and acute, was embodied in the fantastic series of international groupings and combines which we identify as cartels. Probably it will always be a matter of some controversy as to the degree of which cartels accounted for the extreme depression following r929. It is beyond dispute, however, that cartels were among the most direct and immediate causes of the devastation of world markets in the decade which followed.

The onset of world-wide depression to which both shortsighted nationalism and cartel practices had contributed increased, rather than decreased, these strange experiments in the architecture of restriction. New tariffs appeared, more cartels were formed, systems of national barter through bilateral pacts, selective attack by dumping, and all the other stratagems common to "beggar thy neighbor" policies were brought into play. Sorely strained financial resources of countries still struggling under the economic burdens acquired during the war weakened one after another. The depreciation of currencies was inescapable under the circumstances, but the extent to which it might have aided trade cannot be determined, for by that time it required more than exchange stabilization to surmount trade barriers.

But if governments were almost uniformly wanting in respect of their willingness to lift trade restrictions, the cartels were frankly and avowedly intent upon dominating world markets according to their own pattern of "rationalization" and for their own ends. To say that they were frank with respect to their aims, however, is not to say that these aims were matters of public knowledge. The fact that mergers, agreements and alliances were formed might or might not be announced, but seldom, if ever, were the terms or conditions of such affiliation revealed to the public eye. It was characteristic of most of them, in fact, that they were negotiated secretly and carried out in silence. The ensuing paralysis of the world economy had both economic and political effects. For the most part, representative governments were forced to operate in the dark in many basic realms of economic affairs. It is this circumstance which explains in large part their inability to cope with the world trade situation or to bring about a revival of their foreign commerce which might have acted as a direct means of lifting them from depression. Even when governments were willing to relinquish some of the most serious types of discrimination in which they had engaged, both the importance of the industries in which cartels existed and the realm of invisible restraint and exclusion in which they operated made it difficult to expand trade. Necessarily, the operations of cartels affected the balance of trade and the balance of payments of all countries which bought or sold cartelized products. Necessarily, when cartel agreements forbade exports or imports to particular areas, expressions of a desire upon the part of the governments concerned to stimulate the flow of goods were without effect. International investment dwindled while increasing quantities of capital, unable to find productive outlets, were either frozen or moved from one mart to another in search of security and shelter rather than opportunity and expansion. 
Politically, also, the Twenties and Thirties reflected the ascension of the cartel philosophy. In some instances governments sought to regulate cartels. In Europe, especially, cartel control was "a record of failure." Needless to say, this failure was not recognized at the time. Indeed, countries which ostensibly cherished free enterprise went so far as to sanction cartel experiments. Th N.R.A. in the United States was an instance, although a short-lived one, of this tendency. In some cases, however, efforts to control cartels or to use them were prolonged and determined. In Germany, the classic land of the cartel, the most complete fusion of cartels and government occurred.

To review this melancholy cavalcade of economic error which was arrested only by the second World War can be especially valuable in clarifying the problems of trade as they are now before us. From this standpoint there are two aspects of the problem of trade as it confronts the United States. The first is both domestic and unilateral, and is composed of our traditional economic purposes and of those policies toward trade which have been carried over from the past and which will continue to operate in the years ahead. The second aspect is international and multilateral, and involves not only our own action but that of other countries. From both of these perspectives it should be possible for us to draw, at least in outline, a program, or a working diagram of the ends and means of this country in international trade relations.

Before analyzing these elements in any detail there is an all-important proviso which must be made. The principles of economics require effort, foresight, and a mutual willingness to bargain for their successful realization. Trade makes peace fruitful, but the sense of peace is a prerequisite to the beginning of trade. If there is no political security, then we shall witness a resurgence of autarchy, the formation of economic blocs and the swift reappearance of that whole train of restraints and discriminations which followed after World War I. It cannot be stated too emphatically that the success or failure of our efforts to reconstruct world trade must hinge in the first instance upon the success or the failure of our efforts to establish world peace. Only when international political organization has demonstrated that it can assure political security and freedom from fear of aggression, may we reasonably anticipate the wholehearted consent of all nations to trade upon the level of equity.

On the domestic side the dominant factors which enter into our trade policies may be summarized as follows:

I. This nation is committed to a system of free enterprise.

2. Our actions are governed, at least in part, by accumulated laws and practices in the field of tariffs.

3. We have adopted and expect to continue to operate upon the basis of a reciprocal trade program which is itself a very favorable synthesis of our internal and external economic attitudes, oriented toward greater freedom of trade.

${ }^{1}$ Kronstcin \& Leighton, Cartel Control: $A$ Record of Failure (I946) 55 YaLE I. J. 297. 
4. Fundamental to both our national and international economic policies is the opposition to monopoly and combination which is set forth in the Sherman Act.

5. In special circumstances it has also been our policy to permit unity of action among American producers in the export market through Webb-Pomerene associations.

There are, of course, many other elements in our domestic affairs which affect or condition our approach toward international commerce. Thus, there are certain raw materials, relatively few in number, for which we are primarily dependent upon imports. There are certain semi-fabricated goods which rank high upon the list of our industrial requirements and which we obtain from other economic areas. There are certain geographic factors and historic political relationships which exercise a greater or lesser influence upon our conduct of trade or upon our reaction to specific problems. Thus, the Monroe Doctrine and the Good Neighbor Policy have certain economic as well as diplomatic connotations. Finally, although there is general recognition of the desirability of increasing foreign trade, this recognition is coupled with the popular tendency to discount its importance to us. It is true, of course, that foreign trade has accounted for less than Io percent of our national income in the past, and that, as a nation, our economic life is not subject so immediately to the complex interplay of forces in world markets as in the case with many other countries.

What is not understood so clearly is that this circumstance does not by any means emancipate us from the economic tides in other parts of the world. We may not be caught so directly in the ebb and flow of commerce as are the "island" countries or the tropical areas which produce almost wholly for export. Yet, nevertheless, it is impossible for us to dissociate ourselves, even if we should wish to do so, from the long term trend or the periodic, crises which have their center in world markets. We have been a creditor nation since rgrg and we shall continue to be a creditor nation for many years to come. Such a position has both assets and liabilities. It permits us a greater degree of initiative, but it also imposes upon us a greater responsibility. We must grasp the principles upon which our own industrial leadership and our favorable trade position are based since mistakes or shortsighted attitudes toward trade may have repercussions upon the whole framework of international affairs. In justice to our own best interests it must be kept in mind that the margin of trade which is directly connected with our own industrial scene may, nevertheless, be the decisive factor in the maintenance both of our own prosperity and in the gradual achievement of a healthy world economy.

It is impossible to discuss in detail even the principal domestic considerations which form the background of our trade policies. It may be pointed out, however, that there is need for the establishment of a more logical relationship among them in the direction of freeing our own trade, at the same time that we induce greater flexibility and ultimately greater desire on the part of other nations to eliminate 
restrictions. For instance, it must be recognized that it is not enough to seek to increase the volume of our export trade over any period of time unless we are prepared to reduce our own barriers to imports in a corresponding degree. This means that we must evaluate as objectively as can be done those parts of our tariff system which unnecessarily restrict an optimum flow of imports. Such action on our part does not involve either reckless abandonment of safeguards to critical industries, nor does it involve any abrupt or hasty jettisoning of the power to use tariffs as. instruments of policy. Not even the closest adherents of classical "laissez-faire" would today counsel such steps. What is needed is critical thinking, together with a readiness to modify and adapt our tariff structure to a changing economic environment. It would seem only common sense to say that such measures are necessary either for a balanced national economy or for its adjustment to a world economy * It is also essential to proceed on the faith that there are few tariff problems so knotty or so unique that they cannot be discussed or resolved by mutual and reciprocal action between this government and the other nations of the world. The reciprocal trade program constitutes the most direct and most feasible approach to such mutual action.

Among the primary lessons which our war experience has imprinted upon American economic thinking is the meaning of cartels. Our experience on this score has affirmed the principle that monopoly, whether on the national or international level, is inimical to the operation of our system of enterprise and to our international trade position. Whether we consider the technical and research competence of American industry, or the access of our exporters to world markets, or the fulfillment of our official policies in trade, or the continued expansion of our capacity to produce, it is clear that the cartel philosophy is an urgent and formidable menace.

It would seem to be arguing the obvious to say that when American concerns participate in agreements limiting our domestic and foreign commerce by collusion, such acts violate the law as well as do injury to our economic system. Foreign commerce is within the express provisions of the Sherman Act. ${ }^{2}$ If the Sherman Act is to be enforced then private treaties not to produce, nor to export, not to engage in research or not to compete are illegal. Equally, cartel agreements covering primary materials such as metals or manufactured products such as medicinęs, dyes or electrical equipment stand in unmistakable contravention of the laws aimed specifically at conspiracy in trade. Agreements which divide world markets, fix prices, allocate quotas or set limits upon output capacity have the same effect whether their intent is directed toward the domestic market or toward our trade abroad. When large producers at home and abroad attempt by private covenants to achieve domination over great segments of technology and research to forestall the emergence of technical and commercial rivals or to decide among themselves whether given industries shall be introduced in this country, they are not only per-

26 STAr. 209 (1890) as amended, 15 U. S. C. (1940) $5 x$. 
verting the whole spirit of enterprise but they transgress the laws against monopoly.

These assertions are made boldly but they rest upon a quantity of evidence which has accumulated in impressive proportions during the past decade. Even if we omit from discussion the admitted jeopardy to our national security which resulted from monopoly and cartel agreements at the outbreak of World War II, it is still apparent that their implications as manifested by their conduct are contrary to the legal premises controlling our domestic and foreign commerce.

To indicate clearly toward what ends the whole vast machinery of cartels is directed, it will suffice to cite a statement made by an executive of an American company concerning a combine later prosecuted in an antitrust action. The purpose of the cartel was outlined in these words: "May I call the proposed combination for simplicity, a cartel? The whole purpose of the cartel is to obtain a monopoly of patents, so that no one can manufacture it (titanium) excepting the members of the cartel, and so can raise the prices by reason of such monopoly to a point that would give us much more profit on our present tonnage, but also prevent growth in tonnage that would interfere with their greater profits in lithopone (a competing but inferior product).".

The report of a decision rendered by a federal court last year provides a good case study of this cartel. ${ }^{4}$ In 1920 the major manufacturers of titanium dioxide, a new and important white pigment, agreed to divide world markets among themselves and to eliminate free competition from the industry. It was arranged that from time to time subsidiary companies might be formed whose operations would be carried on under the terms of the agreement. As demands for the new product increased over the years such companies were formed in Germany, France and elsewhere and were admitted to membership in the cartel. Upon each such admission the division of territory was reorganized and the scope of exclusive marketing area was reduced. The American concern participating had as its own exclusive territory the North and Central American markets. The German concern received Middle Europe for its own special exploitation. A French manufacturer was given France and French possessions. Other participants were correspondingly accorded exclusive territories. It was this pattern which existed at the time the case was brought.

International trade in titanium pigments was completely controlled. The American concern was barred from exporting to Europe, ordinarily a rather large market which should have been easily accessible under competitive conditions. Not only were the export activities of the American producer severely circumscribed under the various agreements but so were those of other potential American manufacturers and exporters of the product. As is nearly always the case, the operation of the cartel on the international plane produced the parallel effect of domestic monopoly. The presiding judge trenchantly described the condition of the industry when he said: "Every pound of ... (titanium oxide) is trammelled by privately

\footnotetext{
${ }^{3}$ Reported in the opinion in United States v. National Lead Co., 63 F. Supp. 5r3, 522 (S. D. N. Y. 3945).

Ibid.
} 
imposed regulation." ${ }^{\text {Th }}$ The court held, of course, that this cartel clearly violated the antitrust laws. The American producer was ordered to sever its relations with foreign producers and in effect to enter the world market as a free agent.

Every cartelized industry repeats in greater or lesser detail and with variations upon the theme, the pattern of this case. A roster of antitrust cases which have been brought to termination or are pending includes actions against cartels in almost every major field from chemistry to electronics. Their structure and their functions are almost always the same. In effect they have come to constitute an extra-legal system of regulation of international industry.

The arguments that have been advanced recently to support American participation in cartels merit careful scrutiny. Among the principal assertions made by those who believe that this country should accept the cartel system, there are several that require analysis because their surface plausibility is deceptive, and conceals the fundamental fallacies upon which they are based.

It is asserted that American business, even at its strongest, is helpless to compete with cartelized industries abroad, particularly when the latter are supported or subsidized by their governments. This position fails to recognize that under our Reciprocal Trade program, any country which thus discriminates against the commerce of the United States, faces the possibility of losing the American market for its own exports. Presidential powers may be invoked against discrimination originating in cartel activities.

It is claimed that the pressure, of circumstances will tend to make us accept cartels, not only because other nations accept them, but because overproduction in many fields and the inability of demand to match supply will compel American industry to cartelize in order to steady the market. This argument, appealing as it may seem in the case of an individual producer, rests upon one of the major fallacies in economic thought: that there is general overproduction.

The primary goal of trade is an increase in the volume of world production and income. We have long since come to recognize that the principal cause of economic ills is not the general overproduction of goods. Wealth is created only by increasing output and current experience clearly spells out the proposition that there is no substitute which can make up for a scarcity of services and goods. There have been in the past many dislocations and maladjustments of production and many examples of misdirection and waste in the use of resources of capital and of labor but trade is among the simplest and most effective methods of correcting these maladjustments. This is the function of the market in its broadest sense. Interregional trade by fostering the better division of labor and increasing efficiency in the utilization of resources is the major and in some respects the only method which will, over a long run, correct deeply rooted misapplications of economic effort.

Cartel proponents often point to commodity agreements as justification for the

${ }^{5} I d$. at $52 \mathrm{I}$. 
sanctioning of their own activities. To do so they must gloss over the very real distinction between arrangements entered upon by governments for public purposes in pursuance of public policy and with acknowledged public responsibility and agreements made among private producers for private purposes without public responsibility and certainly contrary to public interest as it is embodied in the law.

It is appropriate in considering the cartel problem and the effect of antitrust laws to give some consideration to the meaning of the Webb-Pomerene Act. ${ }^{8}$ This Act was intended primarily to equalize the bargaining position of American exporters vis-à-vis foreign cartels in the world market. Over the years, and with increased emphasis in the past decade, the argument has been advanced that the WebbPomerene Act provides a back door by which American concerns may enter into agreements with cartels abroad and yet escape the jurisdiction of the Sherman Act. This interpretation is contrary both to the purposes of Congress in passing the Webb-Pomerene Act and to the economic interests which the antitrust laws are intended to safeguard.

The Webb Act as finally passed in I9I8 provides that nothing in the Sherman Act shall be construed as declaring to be illegal an export association or any agreement made or act done in the course of export trade by such association, provided that the association agreement or act does not (a) restrain trade within the United States, (b) restrain export trade of any domestic competitor or association, (c) enhance or depress prices within the United States, (d) substantially lessen competion within the United States, or otherwise restrain trade therein. ${ }^{7}$

As it stands the Webb Act is a statute creating an exception to the Sherman Act's given application. Consequently, the principle of interpretation governing all statutes which create exceptions must apply, with the result that the Webb Act must be strictly construed. This meanis that it cannot be taken to cover any more ground than that intended by the language of the act itself, in terms of its legislative history.

As such, the legislative history of the Webb Act leaves no doubt whatever concerning Congressional intention. This is indicated by statements made both by Senator Pomerene and Representative Webb. During debate on the bill Senator Pomerene asserted:

The position was taken in substance that this bill was a repeal of the Sherman Antitrust Law, and if it became the law of the land and these associations were authorized they would at once seek to control the foreign market and probably enter into a combination with foreign companies and cartels engaged in the same line of business and thus reenforced and worldwide in their control of products they would reduce the prices of food animals, of grain, and of other products and raise the prices to the consumer when it suited their purposes.

In the House debates, Mr. Moore of Pennsylvania asked:

"Suppose a combination in which Americans join with foreigners has been formed?"

To this query Mr. Webb replied:

- 40 STAT. 516 (rgI8) 15 U. S. C. (1940) \$\$6I-65.

${ }^{7}$ Sec. 2 of the Act, 15 U. S. C. (1940) $\$ 62$. 
"Then you violate the antitrust law and it has been so held by the court." 8

Later in the Senate debates, Senator Pomerene stated:

"There is nothing in this bill authorizing the division of territory abroad."

Various attempts were made between I92I and I928 to amend this act in the direction of extending the scope of exemptions from the antitrust laws. For example, amendments proposed in 1928 would have permitted combinations for the import of certain raw materials not produced in any substantial quantities in the United States. In effect, this amendment would supposedly have served as a means of coping with foreign monopolies (some of them subsidized by their governments) that controlled the prices paid by American importers. . During the debates on this amendment it was attacked, inter alia, on the ground that if it became law, import associations would be permitted to join the foreign producers in world-wide agreements, dividing the world markets and fixing world prices. Congress indicated its unwillingness to extend the Webb Act by failing to pass such amendments.

It is thus clear that from its inception, it has been understood that the Webb Act does not sanction any activity upon the part of export associations beyond the strict limits of the promotion of our foreign export trade. Collateral or accrued activities, which have in some instances crept into the operation of export associations tending to restrain domestic competitors, or to weaken the competitive position of American industry abroad through cartel agreements, are still illegal under the Sherman Act. There is no novelty of interpretation here. It would seem that the scope of the Webb Act cannot by any stretch of reason be made to include the categories of cartel activity or monopoly behavior against which the Sherman Act is directed.

It should be clear that regardless of what approach may be taken by public authority to rehabilitate trade, there can be no room for the exercise of fundamental economic power by private cartel groups. The risk and the cost alike are too great.

In our own behalf, both with respect to imports which are qualitatively important and with respect to the promotion of our export trade, the logic of our experience affirms the direct connection between the growth of free trade and the prosperity of our own economy. We need only ask ourselves whether it would have been possible for this country to attain its present industrial eminence if the original states of the Union had practiced trade discrimination or if sectional differences had been permitted permanently to prevent an increasing volume of traffic or the gradual establishment of new industry.

There are further aspects which must be taken into account. First, over any reasonable period of time, the practice of discrimination in trade whether it flows from government or from monopoly is self-defeating. It is all very well to pursue trade as a quarry by whatever stratagems are available. What must be understood

53 CoNG. REc. 13536 (19x6).

56 CONG. ReC. $18 \mathrm{I}$ (1917). 
is that trade can grow only in the open market. When attempts are made to hem trade in, to fix its dimensions, or to govern its behavior too rigidly, trade has a definite tendency to vanish altogether. It is for this reason that the perpetuation of undue restrictions not only misses its objective but destroys the possibility of healthy exchange.

In the present period of transition it may seem that the difficulties in the way of working toward greater freedom of trade are nearly insuperable. It may even be that many temporary expeditions will be adopted which are not designed to foster freer markets. At the same time it is imperative to realize that there are no difficulties at the present time which are so great that they can in any way justify the abandonment of freer trade as a goal. Indeed, if history is any guide there is always a danger that temporary restrictions, while they are easy to enact, will become permanent and be increasingly difficult to remove. It is to be hoped, therefore, that whatever measures are taken now on the international plane will be framed in the light of an ultimate increase in the volume of trade. There will then be immense opportunities for American industry, a vast potential demand for American products, and numerous types of profitable investment for American capital.

In terms of the conditions which can, if they are consistently observed, bring about a renaissance of world trade, it is good to note that since the end of the war several steps have been taken which will go far toward reviving world markets and giving new impetus to trade. The United Nations holds forth the promise of political security and the cultivation of a political environment in which fear of aggression no longer exists. The establishment of a world bank and an international fund for reconstruction indicate the desire and the readiness of the nations of the world to stabilize international finance. So, too, the resumption of the Reciprocal Trade program appears to offer a feasible and specific means of working toward the reduction of governmental trade barriers and the stimulation of multilateral commerce. It may be that in the course of the years as trade increases and production grows it will gradually become possible for goods to move freely from one end of the earth to the other and for nations to enter into the international market on the same open basis as that which exists on this continent.

If the world economy is to function as we know it can to elevate the living standards of mankind, to multiply the fruits of labor and to insure the ways of peace, our purposes and our methods must correspond not only to the scale of the present, but to the breadth of vision which guided the nations in war. The free peoples of the world have gained history's greatest victory. To strive for greater freedom in trade is one way in which they can set a mark upon that victory "in a manner worthy of its price." 